Summer 2005

\title{
Pluralistic Deficit and Direct Claims to European Constitutional Courts
}

Serena Baldin

University of Trieste

Follow this and additional works at: https://www.repository.law.indiana.edu/ijgls

Part of the Construction Law Commons, Courts Commons, European Law Commons, and the International Law Commons

\section{Recommended Citation}

Baldin, Serena (2005) "Pluralistic Deficit and Direct Claims to European Constitutional Courts," Indiana Journal of Global Legal Studies: Vol. 12 : Iss. 2 , Article 16.

Available at: https://www.repository.law.indiana.edu/ijgls/vol12/iss2/16

This Symposium is brought to you for free and open access by the Law School Journals at Digital Repository @ Maurer Law. It has been accepted for inclusion in Indiana Journal of Global Legal Studies by an authorized editor of Digital Repository @ Maurer Law. For more information, please contact rvaughan@indiana.edu.

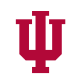

JEROME HALL LAW LIBRARY

INDIANA UNIVERSITY

Maurer School of Law
Bloomington 


\title{
Pluralistic Deficit and Direct Claims to European Constitutional Courts
}

\author{
Serena Baldin*
}

Pluralistic deficit is connected to the difficulties of representing individual and collective interests. From this perspective, access to European Constitutional Tribunals, particularly in the newest Central and Eastern European countries, is broadly guaranteed to persons or organizations, such as constitutional bodies, territorial entities, political parties, labor unions, socioeconomic organizations, and religious associations. With few exceptions, such as Italy and France, European legal systems confer on citizens the option to resort to constitutional courts directly. Where individual direct access is regulated, constitutional jurisdiction works at the ideal level. ${ }^{1}$

This brief approach makes it difficult to discuss pluralistic deficit with reference to constitutional tribunals because the growth of individual and social rights runs parallel to their judicial protection through different sorts of instruments (extensive access, more competencies, expansion of parameters, and types of sentences). ${ }^{2}$ But this situation also produces a paradox: a generalized tendency to increase access to constitutional justice risks diminished accuracy in judgment, prevision of summary proceedings, and minor legal guarantees, as I explain below. In this way, public control and transparency-which are factors strictly connected to pluralism and used to anticipate the outcome of cases and

\footnotetext{
"Researcher of Comparative Public Law at the University of Trieste, Italy; author of Le "altre" funzioni delle corti costituzionali: Modelli europei e recezioni con particolare riferimento all'Est europeo (2000); editor of Diritti tradizionali e religiosi in alcuni ordinamenti contemporanei (2005).

1. See Livio Paladin, La tutela delle libertà fondamentali offerta dalle Corti costituzionali europee: spunti comparatistici, in Le Garanzie Giurisdizionali dei Diritti Fondamentali 11 (Lorenza Carlassare ed., 1988).

2. The recently instituted constitutional courts have broader jurisdiction than the courts created immediately after World War II. Their jurisdiction is broader because, in addition to the constitution and constitutional statutes, they can refer to international treaties (or constitutional customs, fundamental principles, etc.) to verify the conformity of the laws. Moreover, the courts have increased their own power by creating new types of sentences, which permit the court to avoid accepting or rejecting a claim. See Lucio Pegoraro, Lineamenti di giustizia costituzionALE COMPARATA (1998).
} 
thus guarantee legal certainty (and respect for precedent) ${ }^{3}$ - can be seriously affected.

For the reasons explained above, pluralistic deficit before constitutional courts is not so much a problem in terms of lack of representation, but difficulties arise from much more than broad access. This can create disadvantages in functionality within judicial procedure, such as docket control problems and a reduction in the quality of opinions. Consequently, in order to reconcile wide access to courts with a reduction of the pluralistic deficit, a balance must be struck between efficiency and access to justice.

Some examples will elucidate this view, beginning with individual direct claims - which represent the major problem for courts in balancing judicial input and output in such a way that allows them to resolve other claims quickly-and ending with a very brief remark on the access given to local authorities and institutional bodies.

Comparative studies reveal that with respect to judicial review cases, courts are obliged to explain thoroughly the reasoning behind their decisions. This is because courts respond to specialized constituencies, such as advocates, parliament, and other courts, in addition to public opinion. The opposite situation can be seen with regard to individual direct claims where there is a problem of docket control, as Luigi Malferrari stated with reference to the European Community Courts. ${ }^{4}$ To balance judicial input and output with regard to individual direct claims, all remedies introduced or proposed imply a loss in terms of pluralistic guarantees. The necessity of strict case selection is related to modification of the inner workings of the courts, ${ }^{5}$ and this inevitably prejudices the principle

3. See Francesco Rimoli, Pluralismo, in 23 Enciclopedia Givridica 6 (1997); Giuseppe Morbidelli, Introduzione al diritto e all'interpretazione, in Diritto costituzionale ITAliano E comparATo (Giuseppe Morbidelli et al. eds., 1997).

4. See Luigi Malferrari, The Functional Representation of the Individual's Interests before the EC Courts: The Evolution of the Remedies System and the Pluralistic Deficit in the EC, 12 Ind. J. GlobaL LEGAL Stud. 667, 682-83 (2005).

5. The European Court of Human Rights is also currently involved in a functional change that should relieve the workload. The main changes introduced are: in clearly inadmissible cases, the decisions will be taken by a single judge, assisted by nonjudicial rapporteurs; repetitive cases may be declared admissible and decided by a committee of three judges (instead of the present sevenjudge Chamber) under a simplified summary procedure; and the introduction of new admissibility criteria, such as the declaration of an inadmissible application if the applicant has not suffered a significant disadvantage. These changes are regulated in Protocol No. 14 to the Convention for the Protection of Human Rights and Fundamental Freedoms. See Eur. Ct. H.R., Protocol No. 14 $\mathrm{mmmm}$ 
of collegiality and the duty of motivation. ${ }^{6}$ Thus, the lack of democracy that affects constitutional courts is amplified-even if their composition tries to respond to the demands of democratic legitimacy.

The procedural changes, starting from the German Bundesverfassungsgericht, have circulated in other European legal systems, so that there is a strict analogy in the adopted solutions. The remedies are designed to provide constitutional tribunals with the flexibility and the procedural means they need to process all applications in a timely manner, while allowing the tribunals to concentrate on the most important cases that require in-depth examination. ${ }^{8}$ Thus, the preliminary control over the formal requirements is delegated to single judges (such as in Croatia and Poland) or to the administrative apparatus of the courts (such as in Germany, Hungary, and Russia). Few legal systems have introduced preliminary conciliatory instruments that are aimed at immediately withdrawing the claim when the tribunal's administrative apparatus notes that the case does not have any possibility of being accepted by the judges. ${ }^{9}$

After this step, a committee of three judges often complies with the certification of admissibility, evaluating the aspects of objects and constitutional

to the Convention for the Protection of Human Rights and Fundamental Freedoms, Amending the Control System of the Convention, May 13, 2004, available at http://conventions.coe.int Treaty/EN/Treaties/Word/194.doc (last visited Mar. 9, 2005); see also Reform of the European Court of Human Rights, Council of Europe, at http://www.coe.int/T/E/Com/Files/Themes/ECHR/ default.asp (last visited Mar. 9, 2005).

6. The duty of motivation obliges judges to explain the bases of their opinions. Thus, the duty of motivation represents a form of "social" control over the court's activity.

7. The factors that legitimate the courts' composition are pluralism, which must reflect the government's political formation; representativeness, which must include ethnic and linguistic interests of the society; and the professional and technical experiences of the judges. See Louis Favoreu, La legitimité de la justice constitutionnelle et la composition des juridictions constitutionnelles, in Legitimidade e legitimaçao da Justiça constitucional: Colóquio no io a Aniversário do Tribunal Constitucional-Lisboa, 28 e 29 de Maio de 1993, at 236 (José de Souza et al. eds., 1995). We cannot affirm a priori that nomination of the judges is preferable to their election, or vice versa. In both cases, only time will tell whether the decisionmaker's choice was able to guarantee independence and neutrality.

8. See A.A.V.V., L'accès direct à la protection: techniques et résultats, in 7 Annuaire Internationale de Justice Constitutionnelle (1993); Paolo Bianchi, La creazione giurisprudenziale delle tecniche di selezione dei casi (2000); Elisabetta Crivelli, La tutela dei diritti fondaMENTALI E L'ACCESSO alla GiUstizia costituzionale (2003).

9. This is also the case in Germany with the so-called "registration procedure," which allows formal control of the claim before the court intervenes. 
parameters. ${ }^{10}$ In particular, the possibility of rejecting a claim with a very concise opinion, or without even that, if the three judges are unanimous, is a patent erosion of the guarantee of transparency; the duty of motivation succumbs before the principle of procedural economy. But this measure leaves room for abuse: minimal rulings can hide inaccuracies, and therefore damage legal certainty. ${ }^{11}$

Another tool that allows faster resolutions is that the same three-judge panel that composed the committee for admissibility can also be empowered to decide the merits of the case. Obviously, one can object that this measure implies a derogation of the principle of collegiality, which is quite relevant here considering that constitutional sentences cannot be appealed.

Basically, if docket control is too strict, the risk is that the system leaves rights and liberties that are considered minor without protection, as in the cases where claims are rejected in compliance with the Latin motto de minimis non curat praetor. ${ }^{12}$ But if the balance favors the protection of individuals, allowing claimants access to the constitutional courts for any infringement can result in a low standard of reasoning in simple, summary opinions-in other words, a manifestation of pluralistic deficit. Thus, this situation has remarkable effects on the quality of judicial protection for citizens and on the legal certainty of the system.

Another example can be found with local authorities: the constitutional recognition of municipal normative autonomy should be guaranteed before constitutional courts (or administrative tribunals) ${ }^{13}$ for the protection of their competencies, as in the case of federative entities. This is so in the German and the Austrian legal systems and starting from them-for the prestige of the Kelsenian

10. For example, Germany, Spain, Belgium, Slovenia, the Czech Republic, and Poland all employ this process.

11. The contrast that arose in Spain between Tribunal Supremo and Tribunal Constitucional in January and February 2004 is emblematic. The constitutional judges have been condemned by the ordinary judiciary for having rejected a recurso de amparo without deep motivation, thus acting with "grave professional negligence." The Constitutional Tribunal annulled the civil sentence. See Acuerdo del Pleno, at www.tribunalconstitucional.es/ACUERDO\%20DEL\%20PLENO\% 2003022004.htm (last visited Mar. 9, 2005).

12. This solution has been adopted by the European Court of Human Rights. See Eur. Ct. H.R., supra note 5.

13. This requirement is one of the points to be observed by the states adhering to the European Charter of Local Self-Government, Oct. 15, 1985, art. 11, available at http://conventions.coe.int/ Treaty/en/Treaties/Word/122.doc (last visited Mar. 9, 2005) ("Local authorities shall have the right of recourse to a judicial remedy in order to secure free exercise of their powers and respect for such principles of local self-government as are enshrined in the constitution or domestic legislation."). 
model of constitutional justice ${ }^{14}$ that has been imitated in a vast area of Europe $e^{i 5}$ this idea circulated, after the fall of the Berlin Wall, to Slovenia, Montenegro, Poland, Hungary, and most recently, Spain.

The Spanish solution reveals the duality of the approach of the Parliament. This solution allows access, but the conditions required are so strict that, in reality, it is extremely difficult to resort to the judicial body. Since 1999, the year this competence was introduced, few claims have been presented to the Tribunal Constitucional. ${ }^{16}$ This ambiguity reflects the unresolved balance between the costs and benefits of extremely broad access to constitutional justice, which creates a problem of excessive caseloads and a consequent slowing in the resolution of other claims considered more important for the definition and protection of the state's values and for the relationships among and between constitutional bodies.

With reference to access conferred to institutional bodies, parliaments today deem it proper to give constitutional judges functions that are not always constitutional in nature and that could be assigned to other jurisdictional subjects (e.g., ordinary courts, specialized tribunals). As the new constitutional courts of Central and Eastern Europe reveal, there is great confidence in the neutrality and impartiality of these bodies. The result is that they are serving many functions that are not strictly judicial, such as asserting constitutional control over political parties; ${ }^{17}$

14. While in the U.S. model of judicial review of legislation every judge can declare null and void an act that is contrary to the Constitution, in the majority of European countries this power is given only to a specialized court (the constitutional court) that is separate from the judicial branch. This solution was theorized by Hans Kelsen at the beginning of the twentieth century and applied for the first time in Austria with the Constitution of 1920.

15. See Mauro Mazza, La giustizia costituzionale in europa orientale (1997); La justice constitutionnelle en Europe centrale (Marc Verdussen ed., 1997). See generally Giustizia costituzionale e sviluppo democratico nei Paesi dell'Europa centro-orientale (Giuseppe de Vergottini ed, 2000); La démocratie constitutionnelle en Europe centrale et orientale, BILANS et PERSPECTIVes (Slobodan Milacic ed., 1998) (containing numerous articles that discuss the setup of new constitutional courts in Europe).

16. See Tania Groppi, La garanzia dell'autonomia costituzionale degli enti locali: un'analisi comparata, 5 Le Regroni 1021 (1998); Tania Groppi, Il "conflitto a difesa dell'autonomia locale" in Spagna, 28 Le Regioni 35 (2000); Tania Groppi, Spagna: Ammesso il primo conflitto a difesa dell'autonomia locale, in 2001 Diritto Pubblico Comparato ed Europeo 492.

17. For example, this is done in Germany, Portugal, Bulgaria, Romania, Moldova, Poland, Croatia, Slovenia, and Albania. 
over regularity of referenda, ${ }^{18}$ general, ${ }^{19}$ and presidential elections; $;{ }^{20}$ and over judgment on the impeachment of the president. ${ }^{21}$ They also engage in interpretive and consultative activities for constitutional bodies. ${ }^{22}$ These roles are quite different from their "traditional" functions, which are judicial review of legislation and conflict resolution between federation and state members (or states and regions). ${ }^{23}$

These remarks should make parliaments carefully examine the conferral of new powers on constitutional tribunals. When adopted, these new functions should be introduced with streamlined measures to enable courts to resolve cases expeditiously. It is possible that, in the future, some competencies given to constitutional tribunals will be taken away. This is what happened in Italy, where the Constitutional Court, in the wake of the Lockheed scandal, was prevented from resolving other claims for many years, and the function of the impeachment of ministers was reassigned to ordinary jurisdiction in $1989 . .^{24}$

18. For example, Italy, France, Austria, Germany, Portugal, Romania, Croatia, Albania, Slovakia, Moldova, Slovenia, and Hungary allow for this control.

19. For example, Germany, Austria, France, Portugal, Croatia, Bulgaria, Slovakia, Albania, and Moldova allow for this control.

20. For example, France, Austria, Portugal, Romania, Bulgaria, Croatia, Slovakia, and Albania allow this.

21. For example, Germany, Austria, the Czech Republic, Hungary, Slovenia, Croatia, Slovakia, Bulgaria, Albania, Moldova, Romania, and Russia allow this.

22. This is allowed in France, Slovenia, Slovakia, Hungary, Moldova, Poland, and Russia.

23. See Serena Baldin, Le “altre” funzioni delle corti costituzionali: Modelli europei e RECEZIONI CON PARTICOLARE RIFERIMENTO ALL'EST EUROPEO 10 (2000).

24. See Pierpaolo Dell'Anno, Il procedimento per i reati ministeriali (2001). 